\title{
Astronomical calibration of the geological timescale: closing the middle Eocene gap
}

\author{
T. Westerhold ${ }^{1}$, U. Röhl ${ }^{1}$, T. Frederichs ${ }^{2}$, S. M. Bohaty ${ }^{3}$, and J. C. Zachos ${ }^{4}$ \\ ${ }^{1}$ MARUM - Center for Marine Environmental Sciences, University of Bremen, Leobener Straße, \\ 28359 Bremen, Germany \\ ${ }^{2}$ Department of Geosciences, University of Bremen, 28359 Bremen, Germany \\ ${ }^{3}$ Ocean and Earth Science, University of Southampton, National Oceanography Centre, Southampton, SO14 3ZH, UK \\ ${ }^{4}$ University of California, Santa Cruz, California, USA \\ Correspondence to: T. Westerhold (twesterhold@marum.de)
}

Received: 21 April 2015 - Published in Clim. Past Discuss.: 11 May 2015

Revised: 4 September 2015 - Accepted: 7 September 2015 - Published: 23 September 2015

\begin{abstract}
To explore cause and consequences of past climate change, very accurate age models such as those provided by the astronomical timescale (ATS) are needed. Beyond 40 million years the accuracy of the ATS critically depends on the correctness of orbital models and radioisotopic dating techniques. Discrepancies in the age dating of sedimentary successions and the lack of suitable records spanning the middle Eocene have prevented development of a continuous astronomically calibrated geological timescale for the entire Cenozoic Era. We now solve this problem by constructing an independent astrochronological stratigraphy based on Earth's stable 405 kyr eccentricity cycle between 41 and 48 million years ago (Ma) with new data from deepsea sedimentary sequences in the South Atlantic Ocean. This new link completes the Paleogene astronomical timescale and confirms the intercalibration of radioisotopic and astronomical dating methods back through the Paleocene-Eocene Thermal Maximum (PETM, 55.930 Ma) and the CretaceousPaleogene boundary (66.022 Ma). Coupling of the Paleogene $405 \mathrm{kyr}$ cyclostratigraphic frameworks across the middle Eocene further paves the way for extending the ATS into the Mesozoic.
\end{abstract}

\section{Introduction}

Accurate absolute age determinations are essential for the geologic study of Earth history. In recent decades the age calibration of the geological timescale was revolutionized by the discovery of astronomically driven cycles in both terres- trial and marine sedimentary archives (Hilgen, 2010). Development of cyclostratigraphic records and the application of astronomical tuning (Hinnov, 2013) have evolved into powerful chronostratigraphic tools for highly accurate calibration of the Neogene timescale (Lourens et al., 2004), as well as synchronizing the widely used radioisotopic ${ }^{40} \mathrm{Ar} /{ }^{39} \mathrm{Ar}$ and $\mathrm{U} / \mathrm{Pb}$ absolute dating methods (Kuiper et al., 2008). Limits in the accuracy of the astronomically calibrated geological timescale (ATS) are a consequence of uncertainties in astronomical solutions (Laskar et al., 2004, 2011a, b). Earth's orbital eccentricity, the deviation of Earth's orbit around the Sun from a perfect cycle, is widely used for astronomical calibrations (Hilgen, 2010; Hinnov, 2013). Accurate calculations of Earth's short eccentricity cycle, which has an average period of $\sim 100 \mathrm{kyr}$, are currently reliable back to $50 \mathrm{Ma}$ and most likely will never extend beyond $60 \mathrm{Ma}$ (Laskar et al., 2011b; Westerhold et al., 2012) due to chaotic behavior of large bodies within the asteroid belt. Despite this, the long (405 kyr) eccentricity cycle is stable back to $200 \mathrm{Ma}$ and thus serves as a metronome for basic cyclostratigraphic calibration of time series (Hinnov and Hilgen, 2012; Laskar et al., 2004) in Mesozoic and early Cenozoic time. Beyond the $50 \mathrm{Ma}$ limit for short eccentricity multimillionyear-long geological records (Hinnov and Hilgen, 2012) with a $405 \mathrm{kyr}$ eccentricity cyclostratigraphic framework have to be anchored in absolute time (Kuiper et al., 2008) by very precise radioisotopic ages from ash layers.

Because controversy exists regarding the accuracy of highprecision radioisotope dating and astrochronological calibra- 
tions in the Paleocene and Eocene (Kuiper et al., 2008; Westerhold et al., 2012) and the exact age of the Fish Canyon Tuff (FCT) standard for ${ }^{40} \mathrm{Ar} /{ }^{39} \mathrm{Ar}$ dating (Kuiper et al., 2008; Westerhold et al., 2012; Channell et al., 2010; Phillips and Matchan, 2013; Renne et al., 1998, 2010; Rivera et al., 2011; Wotzlaw et al., 2013, 2014; Zeeden et al., 2014), extension of the highly accurate ATS beyond $50 \mathrm{Ma}$ into the early Cenozoic and Mesozoic time is not possible. What is needed is a calibration of the geological timescale in the Eocene and Paleocene that is independent of radioisotopic dating uncertainties and unstable components of astronomical solutions. The best approach is to establish a complete stratigraphic framework for the Cenozoic that is based on the identification of the stable 405 kyr eccentricity cycle and is rooted in the Neogene to late Eocene, where all components of the orbital solutions are stable and uncertainties in radioisotopic ages are negligible. The complete stratigraphic framework will show which published absolute ages within the Eocene and Paleocene epochs, particularly the ages of the Paleocene-Eocene (Westerhold et al., 2007, 2009, 2012; Charles et al., 2011; Hilgen et al., 2010) and Cretaceous-Paleogene boundaries (Kuiper et al., 2008; Hilgen et al., 2010, 2015; Dinarès-Turell et al., 2014; Renne et al., 2013; Westerhold et al., 2008), are correct and consistent with radioisotopic ages (Kuiper et al., 2008; Renne et al., 1998, 2013; Rivera et al., 2011). To date, a complete stratigraphic framework has not been possible due to the lack of well-defined cyclostratigraphic records spanning the middle Eocene (Pälike and Hilgen, 2008).

Herein, we close the middle Eocene gap in orbitally tuned data sets (Aubry, 1995; Pälike and Hilgen, 2008) by developing an integrated stratigraphic framework based on the identification of the stable $405 \mathrm{kyr}$ cycle (Hinnov and Hilgen, 2012) between 41 and $48 \mathrm{Ma}$ using new data from Ocean Drilling Program (ODP) Sites 702 (Leg 114; Shipboard Scientific Party, 1988) and 1263 (Leg 208; Shipboard Scientific Party, 2004) in the South Atlantic Ocean (Fig. 1). This was achieved by establishing a magnetostratigraphy across magnetic polarity Chrons C20r and C21n at Site 1263, then combining this with high-resolution bulk carbon isotope $\left(\delta^{13} \mathrm{C}\right)$ records from Sites 702 and 1263. These new data, together with previously available shipboard stratigraphic data, allow us to construct a robust $405 \mathrm{kyr}$ cyclostratigraphic framework across a $\sim 7 \mathrm{Myr}$ window of the middle Eocene.

\section{Material and methods}

\subsection{Study sites}

For this study we generated new geochemical and paleomagnetic data on carbonate-rich sediments from ODP South Atlantic Site 702 (Leg 114; Shipboard Scientific Party, 1988) and Site 1263 (Leg 208; Shipboard Scientific Party, 2004) (Fig. 1). ODP Site 702 is located in the southwestern South Atlantic on the central part of the Islas Orcadas Rise $\left(50^{\circ} 56.79^{\prime} \mathrm{S}, 26^{\circ} 22.12^{\prime} \mathrm{W}\right)$ in $3083.4 \mathrm{~m}$ water depth. In

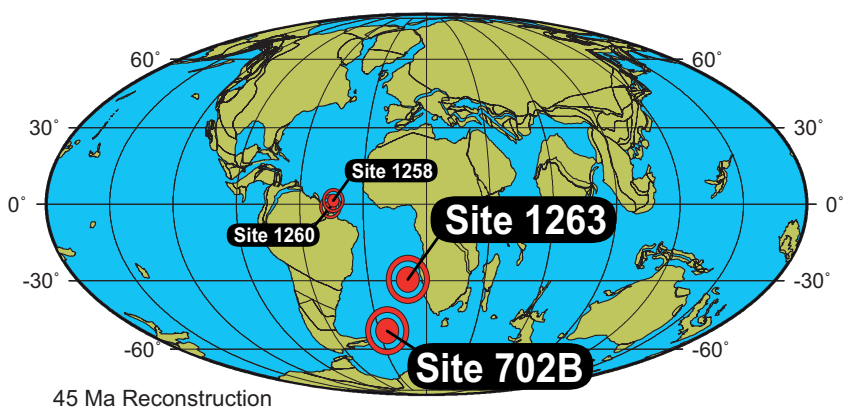

Figure 1. Location map for ODP Hole 702B and Site 1263 on a $45 \mathrm{Ma}$ paleogeographic reconstruction in Mollweide projection (from http://www.odsn.de); also given is the location of ODP Sites 1258 and 1260.

April 1987 only a single hole (Hole 702B) was drilled into Paleogene strata with an extended core barrel (XCB) down to $294.3 \mathrm{~m}$ below sea floor (mbsf), recovering a thick sequence of nannofossil ooze and chalk middle Eocene in age (Shipboard Scientific Party, 1988). For this study, samples were analyzed from Hole $702 \mathrm{~B}$ in the $\sim 90$ and $210 \mathrm{mbsf}$ interval (Fig. 2). ODP Site 1263 is located in the southeastern South Atlantic on Walvis Ridge $\left(28^{\circ} 31.97^{\prime} \mathrm{S}, 2^{\circ} 46.77^{\prime} \mathrm{E}\right)$ at $2717 \mathrm{~m}$ water depth (Shipboard Scientific Party, 2004). At this site, a sequence of Paleogene strata was cored in four adjacent holes that have been combined to a composite record down to $340 \mathrm{~m}$ composite depth (mcd). After revision of the Site 1263 composite record (see below), samples for this study were obtained from the interval between $\sim 150$ and 230 revised meters composite depth (rmcd) of 1263 (Fig. 2).

\subsection{Bulk stable isotope data}

Bulk carbonate $\delta^{13} \mathrm{C}$ measurements were made in two different labs on freeze-dried and pulverized sediment samples from ODP Sites 702 and 1263. A total of 539 samples from Site 702 were analyzed at University of California Santa Cruz (UCSC) between Sections 702B-11X-1 and 702B-22X$\mathrm{CC}$ at an average sampling resolution of $20 \mathrm{~cm}(\sim 13 \mathrm{kyr}$ temporal resolution, Table S1 in the Supplement, Fig. 2). A total of 1157 samples in total were analyzed from Site 1263 (Table S2, Fig. 2). Of these samples, 668 spanning midmagnetochron C19r to mid-C20r were analyzed at MARUM, University of Bremen, with an average resolution of $4 \mathrm{~cm}$ (5 kyr). The remaining 489 samples from Site 1263 spanning mid-C20r to base $\mathrm{C} 21 \mathrm{r}$ were measured at UCSC with average resolution of $10 \mathrm{~cm}(10 \mathrm{kyr})$. All $\delta^{13} \mathrm{C}$ data are reported relative to the Vienna Pee Dee Belemnite (VPDB) international standard, determined via adjustment to calibrated in-house standards and NBS-19. Analyses at MARUM were carried out on a Finnigan MAT 251 mass spectrometer equipped with an automated carbonate preparation line (Kiel I). The carbonate was reacted with orthophosphoric acid at $75^{\circ} \mathrm{C}$. Analytical precision based on replicate analyses of in-house 
a

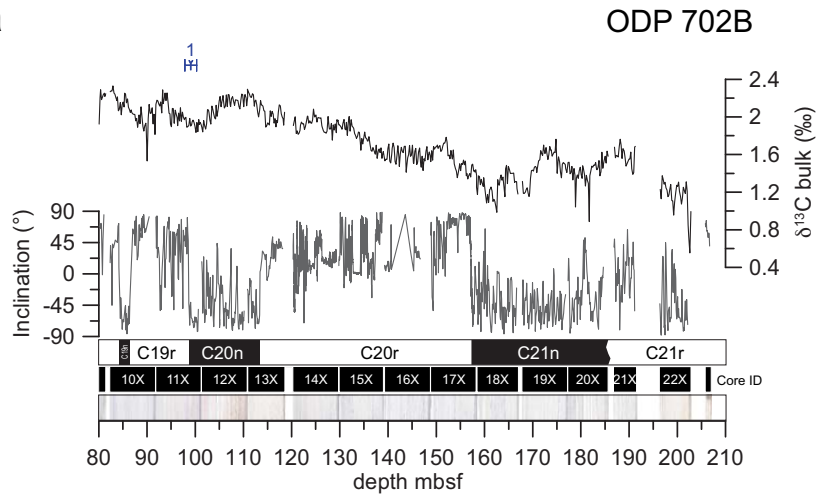

b

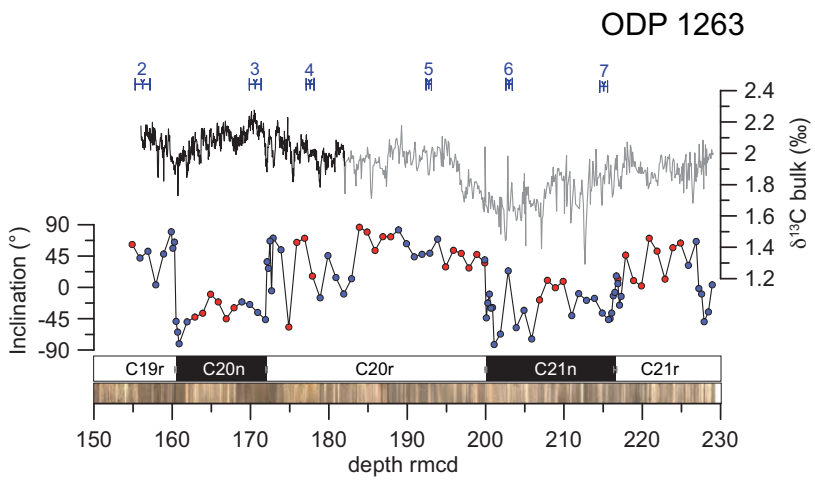

Figure 2. Overview of data from ODP Hole 702B and Site 1263 generated during this study. (a) Bulk stable carbon (black) data generated by this study, inclination data (gray; Clement and Hailwood, 1991), magnetostratigraphic interpretation, core ID and core images vs. depth. (b) ODP Site 1263 data generated by this study vs. revised composite depth: bulk stable carbon isotope data (black: Bremen lab; gray: Santa Cruz lab), inclination data (red dots: 1263A; blue dots: 1263B), magnetostratigraphic interpretation and core images. Numbers with error bars mark calcareous nannofossil events $(2,4)$ : 1, base $R$. umbilicus $>14 \mu \mathrm{m}$; 2 , top Nannotetrina spp.; 3, top $N$. fulgens; 4 , top $C$. gigas; 5 , base $C$. gigas; 6 , base $N$. fulgens; 7 , top D. lodoensis.

standard (Solnhofen Limestone) averages $0.04 \%$ o $(1 \sigma)$ for $\delta^{13} \mathrm{C}$. Stable isotope analyses at UCSC were performed on VG Prism and Optima dual-inlet mass spectrometers coupled with Autocarb automated preparation devices in which the samples are reacted using a carousel device and common acid bath maintained at $90^{\circ} \mathrm{C}$. Analytical precision based on replicate analyses of an in-house Carrara marble standard and NBS-19 averaged $0.05 \%$ o $(1 \sigma)$ for $\delta^{13} \mathrm{C}$.

\subsection{Paleomagnetic data, Site 1263}

We measured natural remanent magnetization (NRM) on 100 discrete cube samples (gauge $2 \mathrm{~cm} \times 2 \mathrm{~cm} \times 2 \mathrm{~cm}$ ) to document magnetic polarity boundaries $\mathrm{C} 19 \mathrm{r}$ to $\mathrm{C} 21 \mathrm{r}$ at ODP Site 1263. Discrete samples were analyzed at the Depart- ment of Geosciences, University of Bremen. Paleomagnetic directions and magnetization intensities were measured on a cryogenic magnetometer (2G Enterprises model 755 HR). NRM was measured on each sample before being subjected to a systematic alternating field demagnetization treatment involving steps of 7.5, 10, 15, 20, 25, 30, 40 and $60 \mathrm{mT}$. Intensities of orthogonal magnetic components of the remanent magnetization were measured after each step. Raw inclination, declination, and intensity data for each measurement step are provided in Table S3, and the magnetostratigraphic interpretations are recorded in Table S4.

\subsection{Time series analysis}

To investigate Milankovitch-paced cyclicity in our data sets, we calculated evolutionary spectra in the depth and time domain to identify the dominant cycle periods and to detect distinct changes in these cycle periods. In order to obtain a first-order age model unaffected by astronomical tuning, we applied the magnetostratigraphy available for Sites 702 (Clement and Hailwood, 1991) and 1263 (this study, Table S3) using the geomagnetic polarity timescale of Cande and Kent (1995). Wavelet analysis was used to compute evolutionary spectra using software provided by $\mathrm{C}$. Torrence and G. Compo (available online at http://paos.colorado.edu/ research/wavelets). Prior to wavelet analysis the data were detrended and normalized. Multitaper method (MTM) spectra were then calculated with the SSA-MTM Toolkit (Ghil et al., 2002) using three tapers and a resolution of two. Background estimate and confidence levels (90, 95 and 99\%) are based on robust red-noise estimation (Mann and Lees, 1996). Prior to analysis, outliers and the long-term trend were removed, and the time series was linearly resampled at $4 \mathrm{kyr}$ (Site 702) and $2 \mathrm{kyr}$ (Site 1263) intervals. After identification of the frequency and period of the short and long eccentricity-related cycles in the bulk $\delta^{13} \mathrm{C}$ data of both study sites, the $405 \mathrm{kyr}$ cycle was extracted by band-pass filtering.

\section{Results}

All data are available online at http://doi.pangaea.de/10. 1594/PANGAEA.845986.

\subsection{Revised composite record for ODP Site 1263}

In order to ensure a fully complete stratigraphic record at Site 1263, we checked the shipboard composite record using shipboard magnetic susceptibility data and digital line scan high-resolution core images (Fig. S1 in the Supplement). Small changes on the order of centimeters to a few decimeters were applied to optimize the splice and avoid coringinduced disturbance in the isotope data. A major change had to be made around $120 \mathrm{rmcd}$, which was reported as problematic during shipboard analysis (Shipboard Scientific Party, 2004). Core $1263 \mathrm{C}-2 \mathrm{H}$ was moved downwards by $2.52 \mathrm{~m}$ to 
match the base of Core 1263B-6H. Core 1263B-7H was then re-correlated to Core $1263 \mathrm{C}-7 \mathrm{H}$ by moving the core $3.34 \mathrm{~m}$ downward. Although this tie is difficult due to core disturbance, the core images provided a good reference. This tie does not affect the record presented in this study because it is located at $125 \mathrm{rmcd}$ and will be re-evaluated by additional bulk isotope data in the future. The composite splice was revised here down to $229.22 \mathrm{rmcd}$. Below this level, there is strong drilling disturbance across a 3-4 m interval. For completeness we report the full composite splice and offsets applied to adjust each core for Site 1263 in Tables S7 and S8.

\subsection{Magnetostratigraphic results and interpretation}

A detailed vector analysis according to the method by Kirschvink (Kirschvink, 1980) without anchoring to the origin of the orthogonal projections was applied to the results of the AF demagnetization of NRM to determine the characteristic remanent magnetization (ChRM). Additionally, the maximum angular deviation (MAD) values were computed reflecting the quality of individual magnetic component directions. MAD values are all below $10^{\circ}$ (Fig. 3).

Figures $3 \mathrm{~b}$ and $3 \mathrm{c}$ display the demagnetization characteristics of a sample with reversed polarity from C19r and a sample with normal polarity from $\mathrm{C} 21 \mathrm{n}$, respectively. As an example for samples with demagnetization behavior with larger scatter (larger MAD), data from a sample within C21r are plotted in Fig. 3d. The larger MADs that a few samples show are not simply related to the intensity of their remanent magnetization as can be seen from the data shown in Fig. 3. The median destructive field (MDF) of the NRM demagnetization is comparably low for most of the samples. It ranges from 4 to $24 \mathrm{mT}$ (mean $7.1 \pm 4.1 \mathrm{mT}$ ), indicating a magnetically soft overprint in many samples. The interpretation of the ChRM in terms of magnetic polarity is focused on the inclination data, which provide a reliable magnetostratigraphy for most intervals. Identification and position of calcareous nannofossil events in Hole 702B (Pea, 2011) and Site 1263 (Shipboard Scientific Party, 2004) (Fig. 2; Table S5) allow for the magnetic chrons to be clearly identified as C19r, C20n, C20r, $\mathrm{C} 21 \mathrm{n}$ and $\mathrm{C} 21 \mathrm{r}$. Raw inclination, declination, and intensity data for each measurement step for ODP 1263 are given in Table S3. Magnetostratigraphic interpretation is given in Table S4. Processed paleomagnetic data from ODP 1263 basis for the magnetostratigraphic interpretation are provided in Table S9.

\subsection{Bulk stable isotope results}

The bulk carbon stable isotope data of Hole 702B (Fig. 2a) show a long-term increase from 0.8 to $2.0 \%$ in the interval Chron C21r to C18r. Site 1263 data (Fig. 2b) reveal a decrease from 2 to $1.6 \%$ from Chron $\mathrm{C} 21 \mathrm{r}$ to $\mathrm{C} 21 \mathrm{n}$, an increase from 1.6 to $2 \%$ across the $\mathrm{C} 20 \mathrm{r}-\mathrm{C} 21 \mathrm{n}$ boundary, a slight increase to $2.2 \%$ in the interval covering the mid-
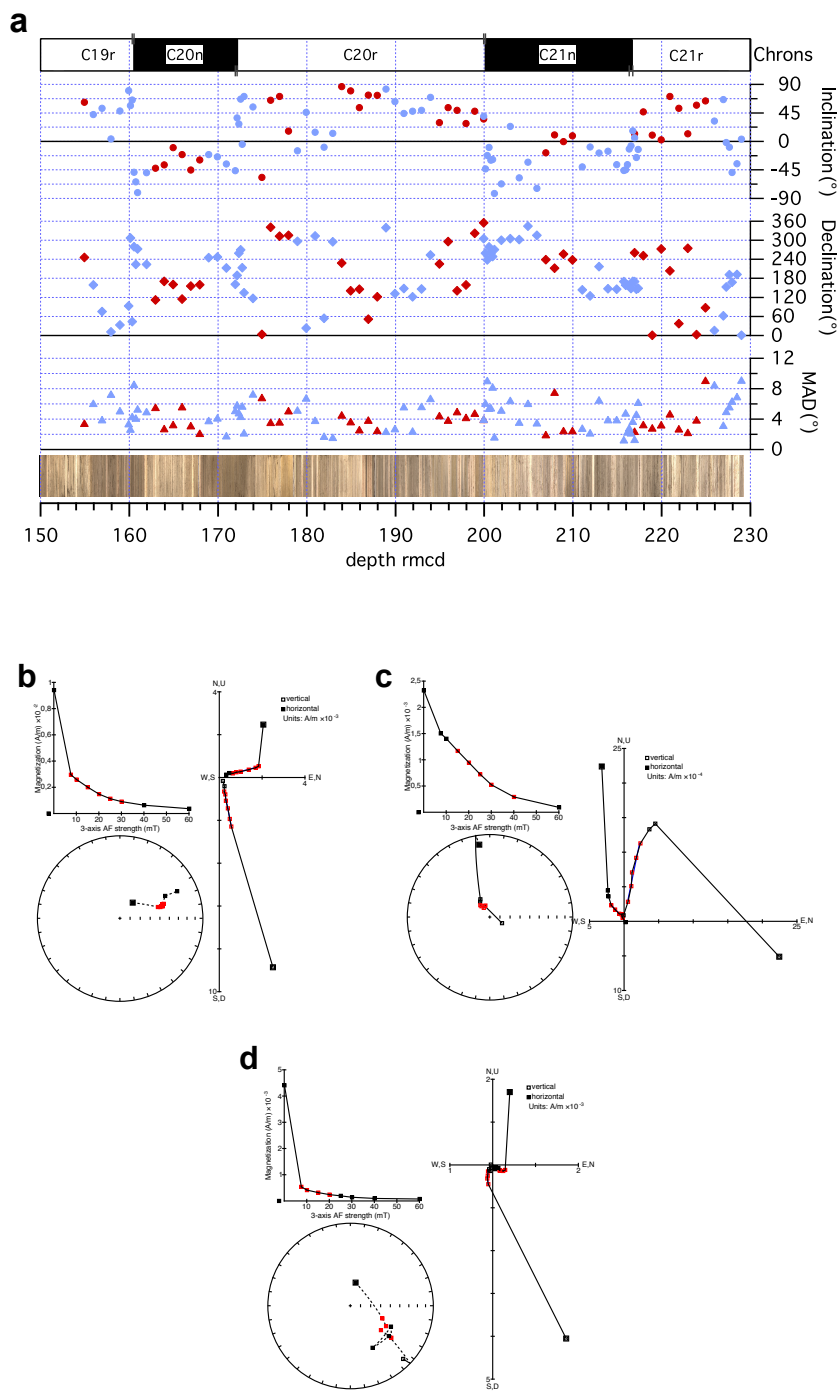

Figure 3. Magnetic property data and Zijderveld plots for ODP Site 1263. (a) Inclination (dots), declination (diamonds) and MAD (triangles) of characteristic remanent magnetization obtained from ODP 1263. Red: 1263A; blue: 1263B. (b-d) Showcase Zijderveld plots (Z plots) for samples from C19r 1263B10H1, $140 \mathrm{~cm}$ (b); C21n 1263B14H5, $77 \mathrm{~cm}$ (c); C21r 1263A21H6, $81 \mathrm{~cm}$ (d). Zijderveld plots were realized with PuffinPlot software (Lurcock and Wilson, 2012). For discussion see text.

Chron C20r to C20n, a decrease of $0.2 \%$ in Chron C20n, and an increasing trend in the early Chron C19r. The shift in carbon isotope data across the $\mathrm{C} 20 \mathrm{r}-\mathrm{C} 21 \mathrm{n}$ boundary and the decrease in Chron C20n is very similar in both records, pointing to global changes in the global carbon cycle. Both records show pronounced higher-frequency variations related to short (100 kyr) and long (405 kyr) eccentricity cycles (see below). 


\section{Age model development}

The age model for Sites 702 and 1263 was developed in a progressive series of steps. First, time series analysis was applied to the bulk $\delta^{13} \mathrm{C}$ data from both Sites 702 and 1263 using evolutionary wavelet (Fig. 4) and MTM power spectra (Figs. S2 and S3). The Site $702 \delta^{13} \mathrm{C}$ record is dominated by $6-8 \mathrm{~m}$ and $\sim 2 \mathrm{~m}$ cycles, whereas Site 1263 is dominated by $3.5-4.5 \mathrm{~m}$ and $\sim 1 \mathrm{~m}$ cycles. Conversion to age applying the geomagnetic polarity timescale (GPTS) CK95 (Cande and Kent, 1995) reveals that these cycles correspond to the short $(\sim 100 \mathrm{kyr})$ and long $(405 \mathrm{kyr})$ eccentricity periods - similar to observations in early (Zachos et al., 2010) and late Eocene (Westerhold et al., 2014) deep-sea sediments.

Second, the dominant $405 \mathrm{kyr}$ related cycles were extracted by band-pass filtering at the appropriate interval (Fig. 5; Site 702: $0.16 \pm 0.048$ cyc. $^{-1}$; Site 1263: $155-180 \mathrm{rmcd} \quad 0.29 \pm 0.087 \quad$ cyc. $\mathrm{m}^{-1}, \quad 180-230 \mathrm{rmcd}$ $0.23 \pm 0.069$ cyc. $\mathrm{m}^{-1}$ ). After correlating the Site 702 and 1263 records via magneto-stratigraphic tie points, a relative floating $405 \mathrm{kyr}$ age model was established by counting cycles starting with 1 in the Site 1263 record at $158.60 \mathrm{rmcd}$ (Table S6). We determine a 2.6 to $2.7 \mathrm{Myr}$ duration for magnetochron $\mathrm{C} 20 \mathrm{r}$ and a $1.4 \mathrm{Myr}$ duration for magnetochron $\mathrm{C} 21 \mathrm{n}$. Our new estimate for the duration of C20r is consistent with estimates from the standard CK95 (Cande and Kent, 1995) and GPTS2004 (Ogg and Smith, 2004) as well as a previous cyclostratigraphic estimate from the Contessa Highway section in Italy (Jovane et al., 2010); however, it is $\sim 400 \mathrm{kyr}$ shorter than that estimated within the GPTS 2012 timescale (Ogg, 2012; Vandenberghe et al., 2012) (Fig. 5, Tables 1-2).

Third, the floating $405 \mathrm{kyr}$ age model was connected to the astronomical timescale (ATS) by correlation to ODP Site 1260 (Westerhold and Röhl, 2013; Westerhold et al., 2014) over magnetochron C20n (Fig. 6a). Site 1260 is tied to the cyclostratigraphic framework for the late middle Eocene-early Oligocene interval (Westerhold et al., 2014) and therefore establishes an independent bridge between the astronomically calibrated timescales of the Neogene to late Eocene and early Paleogene. The correlation and calibration of the cyclostratigraphic records from Sites 702 and 1263 place the boundary of magnetochron $\mathrm{C} 20 \mathrm{n}-\mathrm{C} 20 \mathrm{r}$ in $405 \mathrm{kyr}$ cycle 108 (43.5 Ma), the C20r-C21n boundary between $405 \mathrm{kyr}$ cycle 114 and 115 ( 46.2 Ma), and the C21nC21r boundary in $405 \mathrm{kyr}$ cycle 118 ( $\sim 47.6 \mathrm{Ma})$ (Fig. 5; Tables 1 and 2).

Fourth, because the orbital solutions La2010d (Laskar et al., 2011a) and La2011 (Laskar et al., 2011b) are valid back to $\sim 50 \mathrm{Ma}$ and the pattern of long and very long eccentricitycycle-related components in both the Site 702 and 1263 bulk $\delta^{13} \mathrm{C}$ records are very consistent with the La2010d and La2011 orbital solution for eccentricity, the carbon isotope records were minimally tuned to the La2011 eccentricity by correlating lighter (more negative) $\delta^{13} \mathrm{C}$ peaks to eccentric- a
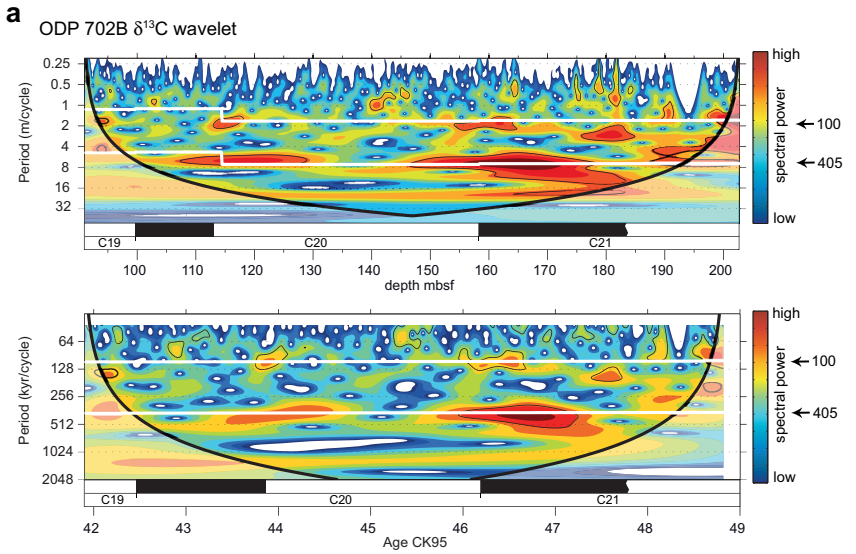

b ODP $12638^{13} \mathrm{C}$ wavelet
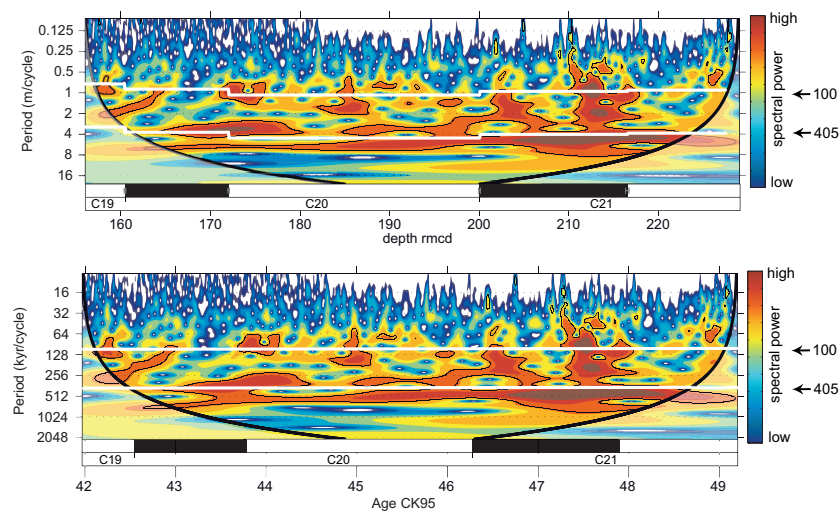

Figure 4. Evolutionary wavelet power spectra of bulk stable carbon isotope data from ODP Hole 702B (a) and Site 1263 (b) for magnetochrons $\mathrm{C} 19 \mathrm{r}$ to $\mathrm{C} 21 \mathrm{r}$ in the depth domain and versus age. The age model is based on magnetostratigraphy using the timescale of Cande and Kent (1995). The shaded contours in the evolutionary wavelet power spectra are normalized linear variances, with blue representing low spectral power and red representing high spectral power. The black contour lines enclose regions with more than $95 \%$ confidence. Shaded regions on either end indicate the cone of influence where edge effects become important. Distinct bands that run across the spectra indicate the dominance of Milankovitch frequencies. The top and bottom thick white lines are the projected 100 and $405 \mathrm{kyr}$ cycle path, respectively.

ity maxima (Fig. 5; Ma et al., 2011). This phase relationship has been observed in other deep-sea $\delta^{13} \mathrm{C}$ bulk and benthic records (Pälike et al., 2006; Westerhold et al., 2014; Zachos et al., 2010) and thus is used here for the foundation of the tuning method (see Supplement). The tie points to establish an astronomically tuned age model are shown in Fig. 5 and listed in Table S10.

A potential issue in establishing a $405 \mathrm{kyr}$-based cyclostratigraphy is the missing or doubling of a $405 \mathrm{kyr} \mathrm{cy}-$ cle. Because the band-pass filter at cycle 10 at Site 1263 shows a conspicuous cycle with a double hump (Fig. 5) and a stretched cycle 9 at Site 702, we also provide an alternative $405 \mathrm{kyr}$ age model with one additional $405 \mathrm{kyr}$ cy- 
Table 1. Comparison of absolute magnetochron boundary ages in millions of years.

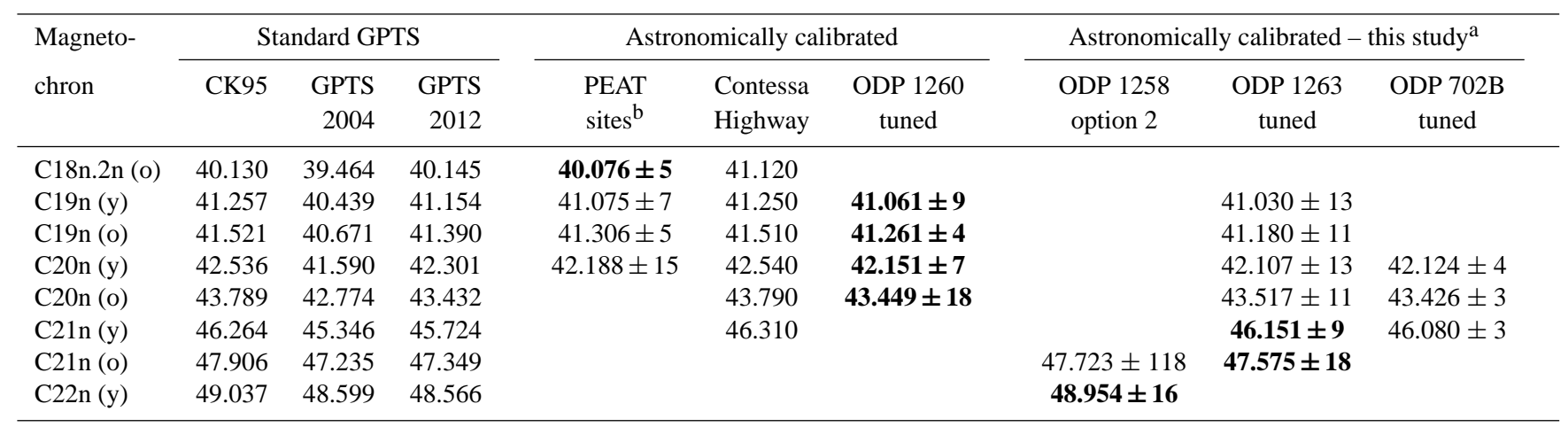

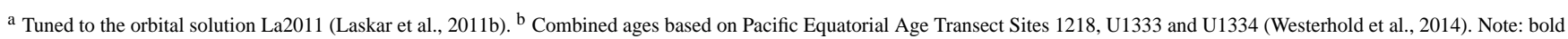
ages are the best estimates to be used for developing a future reference timescale for polarity chrons.

Table 2. Comparison of magnetochron boundary durations in millions of years.

\begin{tabular}{|c|c|c|c|c|c|c|c|c|c|}
\hline \multirow{2}{*}{$\begin{array}{l}\text { Magneto- } \\
\text { chron }\end{array}$} & \multicolumn{3}{|c|}{ Standard GPTS } & \multicolumn{3}{|c|}{ Astronomically calibrated } & \multicolumn{3}{|c|}{ Astronomically calibrated - this study ${ }^{\mathrm{a}}$} \\
\hline & CK95 & $\begin{array}{r}\text { GPTS } \\
2004\end{array}$ & $\begin{array}{r}\text { GPTS } \\
2012\end{array}$ & $\begin{array}{l}\text { PEAT } \\
\text { sites }^{b}\end{array}$ & $\begin{array}{l}\text { Contessa } \\
\text { Highway }\end{array}$ & $\begin{array}{l}\text { ODP } 1260 \\
\text { tuned }\end{array}$ & $\begin{array}{l}\text { ODP } 1258 \\
\text { option } 2\end{array}$ & $\begin{array}{c}\text { ODP } 1263 \\
\text { tuned }\end{array}$ & $\begin{array}{l}\text { ODP } 702 B \\
\text { tuned }\end{array}$ \\
\hline C18n.2r & 1.127 & 0.975 & 1.009 & $0.999 \pm 12$ & & & & & \\
\hline $\mathrm{C} 19 \mathrm{n}$ & 0.264 & 0.232 & 0.236 & $0.231 \pm 12$ & 0.260 & $0.200 \pm 7$ & & $0.150 \pm 24$ & \\
\hline C19r & 1.015 & 0.919 & 0.911 & $0.882 \pm 20$ & 1.030 & $0.891 \pm 6$ & & $0.927 \pm 24$ & \\
\hline $\mathrm{C} 20 \mathrm{n}$ & 1.253 & 1.184 & 1.131 & & 1.250 & $1.297 \pm 13$ & & $1.410 \pm 24$ & $1.302 \pm 7$ \\
\hline $\mathrm{C} 20 \mathrm{r}$ & 2.475 & 2.572 & 2.292 & & 2.520 & & & $2.634 \pm 20$ & $2.654 \pm 6$ \\
\hline $\mathrm{C} 21 \mathrm{n}$ & 1.642 & 1.889 & 1.625 & & & & & $1.424 \pm 27$ & \\
\hline $\mathrm{C} 21 \mathrm{r}$ & 1.131 & 1.364 & 1.214 & & & & $1.231 \pm 134$ & & \\
\hline
\end{tabular}

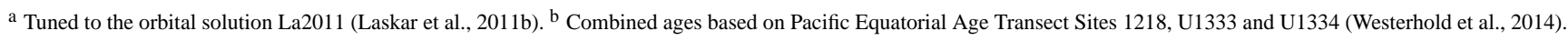

cle (18 instead of 17 for the investigated interval of this study). Sedimentation rates calculated based on the $17 \mathrm{cy}-$ cles, the 18 cycles, and the magnetostratigraphic (using CK95) and the astronomical age model show a distinct drop using the 18-cycles model with respect to the other models (Fig. S5). Choosing the 18-cycles model would therefore lead to an unrealistically long duration for Chron C20r of more than 3.0 Myr. In addition, the orbital solutions La2010d and La2011 are valid back to $\sim 50 \mathrm{Ma}$, and thus the match between the geological record and the astronomical solution as far as the expression of the $2.4 \mathrm{Myr}$ minima provides an important argument for rejecting the presence of a potential extra $405 \mathrm{kyr}$ cycle (Fig. 5). Based on these arguments we discarded the $18405 \mathrm{kyr}$ cycles model as an option.

By connecting the astronomically calibrated Site 1263 $\delta^{13} \mathrm{C}$ record with the geochemical records of ODP Sites 1258 and 1262 we can extend the ATS into the early Paleogene up to the Cretaceous-Paleogene (K-Pg) boundary based on a continuous $405 \mathrm{kyr}$ cyclostratigraphic framework. Not only does this allow for comparison of the eccentricity related components in the geochemical records to the recent orbital solutions La2010 and La2011, it also provides accurate absolute ages for ash -17 , the Paleocene-Eocene Ther- mal Maximum (PETM) and the K-Pg boundary independent of radioisotopic dating and uncertainties in the $100 \mathrm{kyr}$ and 2.4 Myr eccentricity cycle components. Using bulk and benthic $\delta^{13} \mathrm{C}$ records as well as magnetostratigraphy, Site 1258 (Sexton et al., 2011) and Site 1263 (this study) can be tied together at $405 \mathrm{kyr}$ cycles 118 and 119 over the magnetochron C21n-C21r boundary (Fig. 6b). This establishes the connection of the early Paleogene cyclostratigraphies with the ATS of the Neogene and late Paleogene, where all components of the orbital solutions are stable and uncertainties in radioisotopic ages are very small. Closing the middle Eocene cyclostratigraphic gap establishes a complete and fully astronomically calibrated geological timescale for the Cenozoic and is the basis for extending the ATS into the Mesozoic.

\section{Discussion}

Integration of new and previously published results from ODP Sites 1258, 1260, 1262, and 1263 allows (i) placement of these records on a common $405 \mathrm{kyr}$ cycle astronomically calibrated timescale across the middle Eocene and (ii) evaluation of the evolution of Earth's eccentricity in the context 

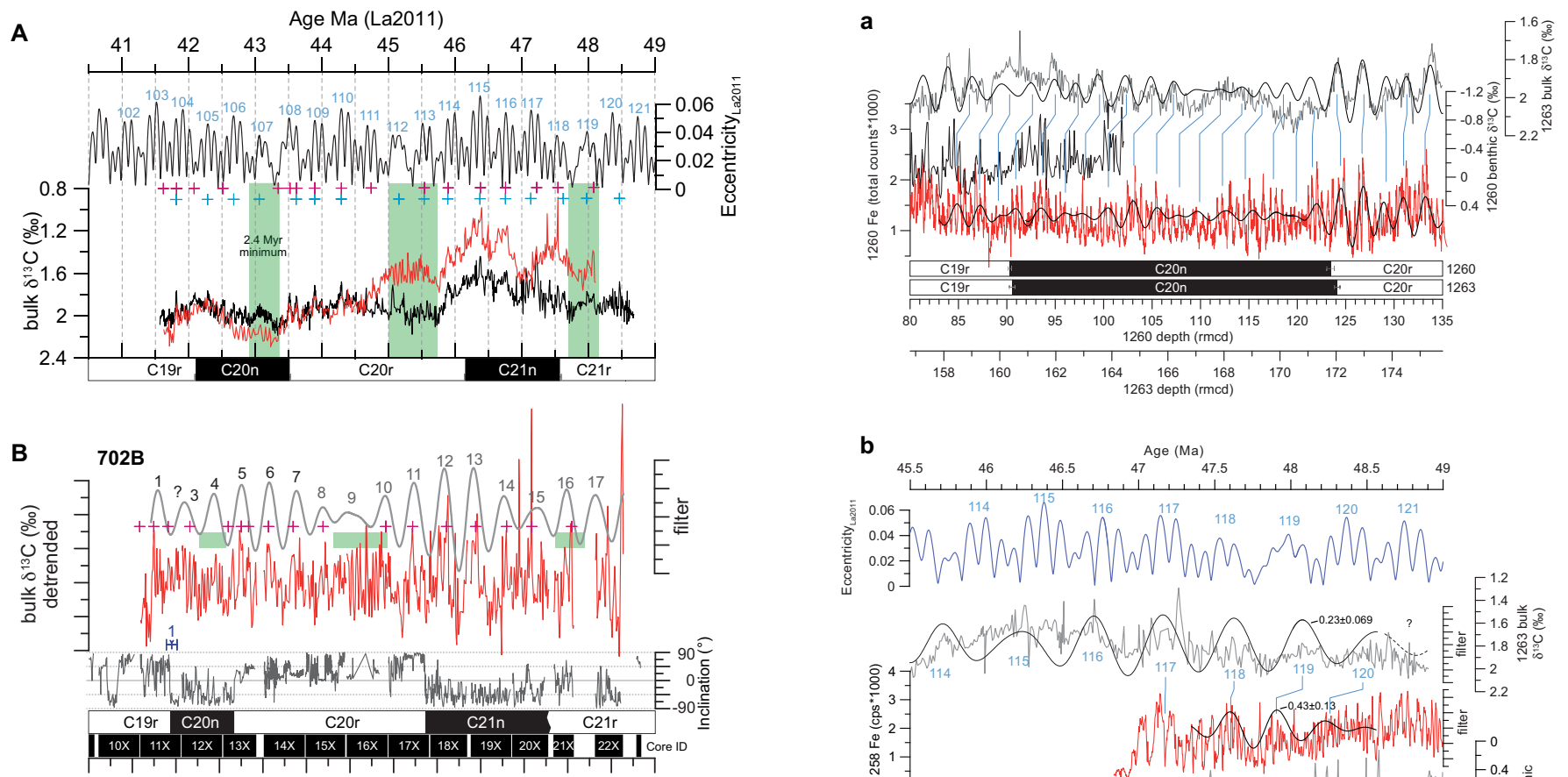

$80 \quad 90 \quad 100110120130140150160170180190200210$

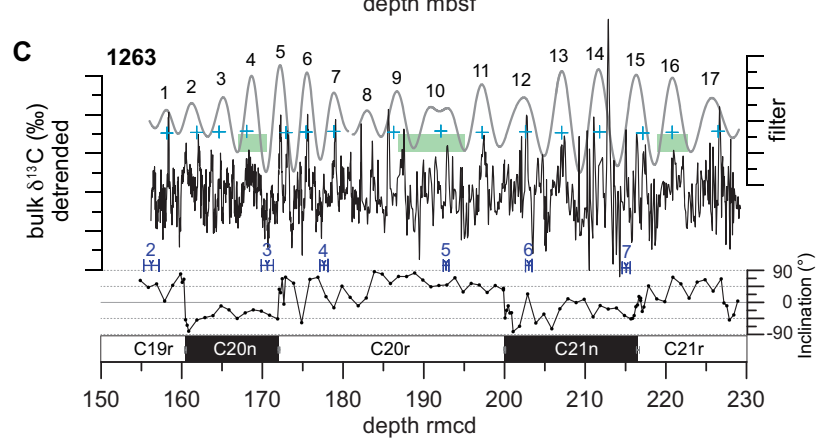

Figure 5. Middle Eocene cyclostratigraphic synthesis for ODP Sites 702 and 1263, 41-48.5 Ma. (a) Orbital eccentricity solution La2011 (Laskar et al., 2011b) and respective 405 kyr cycle number with new astronomical calibrated ages for magnetic polarity chrons C20n, C20r and C21n. Bulk stable isotope data from Sites 702 (red) and 1263 (black) on the new astronomically tuned age model. Green bars show the minima in the amplitude modulation related to the 2.4 Myr cycle in eccentricity. (b, c) ODP Site 702 and 1263 detrended bulk stable isotope data and band-pass filter of the $405 \mathrm{kyr}$ related eccentricity component (Site 702: $0.16 \pm 0.048$ cyc. m ${ }^{-1}$; Site 1263: $155-180 \mathrm{rmcd} 0.29 \pm 0.087 \mathrm{cyc}^{-1}, 180-230 \mathrm{rmcd}$ $0.23 \pm 0.069$ cyc. $\mathrm{m}^{-1}$ ), paleomagnetic inclination (Clement and Hailwood, 1991), calcareous nannofossil events (Pea, 2011; Shipboard Scientific Party, 2004), core recovery for Site 702. Black numbers indicate individual $405 \mathrm{kyr}$ cycles determined by combining records from both sites. Red and blue crosses indicate tuning tie points. Calcareous nannofossil events: 1, base R. umbilicus $>14 \mu \mathrm{m}$; 2, top Nannotetrina spp.; 3, top N. fulgens; 4, top C. gigas; 5 , base $C$. gigas; 6 , base $N$. fulgens; 7, top D. lodoensis.

of the latest generation of astronomical models for intervals older than $50 \mathrm{Ma}$. 


\subsection{Consistent absolute ages for the Paleogene}

To assemble a complete Eocene GPTS, we combined the GPTS of the Pacific Equatorial Age Transect (PEAT, 31$41 \mathrm{Ma}, \mathrm{C} 12 \mathrm{n}$ to C19n; Westerhold et al., 2014), of Site 1260 (41-43 Ma, C19n to C20n; Westerhold and Röhl, 2013), of Site 1263 (42-48 Ma, C20n to C21n; this study), and of Site 1258 (48-54 Ma, C21n to C24n; Westerhold and Röhl, 2009) and updated to the age model established in this study (Tables S11 and S12, Fig. 7).

The resulting Eocene GPTS covers magnetochron $\mathrm{C} 12 \mathrm{n}$ to $\mathrm{C} 24 \mathrm{n}$, and together with the recalibrated early (C29n to C27n, Dinarès-Turell et al., 2014) and late Paleocene (C26 to C24r; option 2 in Westerhold et al., 2008) as well as Oligocene (C6Cn to C12n; Pälike et al., 2006) it provides a full GPTS for the Paleogene period. The new tuned GPTS and the GPTS2012 (Ogg, 2012; Vandenberghe et al., 2012) are nearly consistent. Differences with respect to GPTS2012 are apparent for the duration of C20r, C22r and C23n.2n (Fig. 7a). The 2.634 Myr duration for C20r interpreted in this study is consistent with estimates from the standard CK95 GPTS (Cande and Kent, 1995) and GPTS2004 (Ogg and Smith, 2004) as well as a previous cyclostratigraphic estimate from the Contessa Highway section in Italy (Jovane et al., 2010). The difference for the duration of $\mathrm{C} 20 \mathrm{r}$ to the estimate in GPTS2012 could be related to the selection of tie points for calibration of the GPTS. In GPTS2012 the astronomic age model with a 6-order polynomial fit in the Eocene and the radioisotopic age model give an absolute age for the top of C22n of 49.102 and $48.570 \mathrm{Ma}$, respectively (Vandenberghe et al., 2012, Table 28.3 therein). This difference of $536 \mathrm{kyr}$ mirrors the uncertainty in this interval of the timescale GPTS2012. However, the radioisotopic ages are primarily used for the final age model in GPTS2012 from C16r to the top of C24n.1n (37-53 Ma; Vandenberghe et al., 2012). GPTS2012 uses the Mission Valley ash near the base of C20n with ${ }^{40} \mathrm{Ar} /{ }^{39} \mathrm{Ar}$ age of $43.35 \mathrm{Ma}$, which is consistent with our tuned age of $43.517 \mathrm{Ma}$ for the base of C20n. Because of the relatively large error in the next calibration point (an ash horizon in DSDP Hole 516F at C21n.75 with an age of $46.24 \pm 0.5 \mathrm{Ma}$; Vandenberghe et al., 2012), the duration of C20r in GPTS2012 (2.292 Myr) has to be considered with caution. The differences in duration of C22r and C23n.2n ( 400 kyr longer C22r; $\sim 400 \mathrm{kyr}$ shorter C23n.2n) could be related to the difficult interpretation of the Site 1258 magnetostratigraphy (Westerhold and Röhl, 2009) and require recovery of additional high-quality records from deep-sea successions in the future for confirmation. This uncertainty in the duration of $\mathrm{C} 22 \mathrm{r}$ and $\mathrm{C} 23 \mathrm{n} .2 \mathrm{n}$ at Site 1258 does not affect the number of $405 \mathrm{kyr}$ cycles identified in this record but is the result of uncertainties in determining the exact position of the magnetic reversal. This is complicated by the rather large error in the width of the magnetic anomaly profiles for $\mathrm{C} 21 \mathrm{r}(12.8 \%), \mathrm{C} 22 \mathrm{r}(11.9 \%)$ and C23 (17.3\%) (Cande and Kent, 1992, Table 4 therein), which
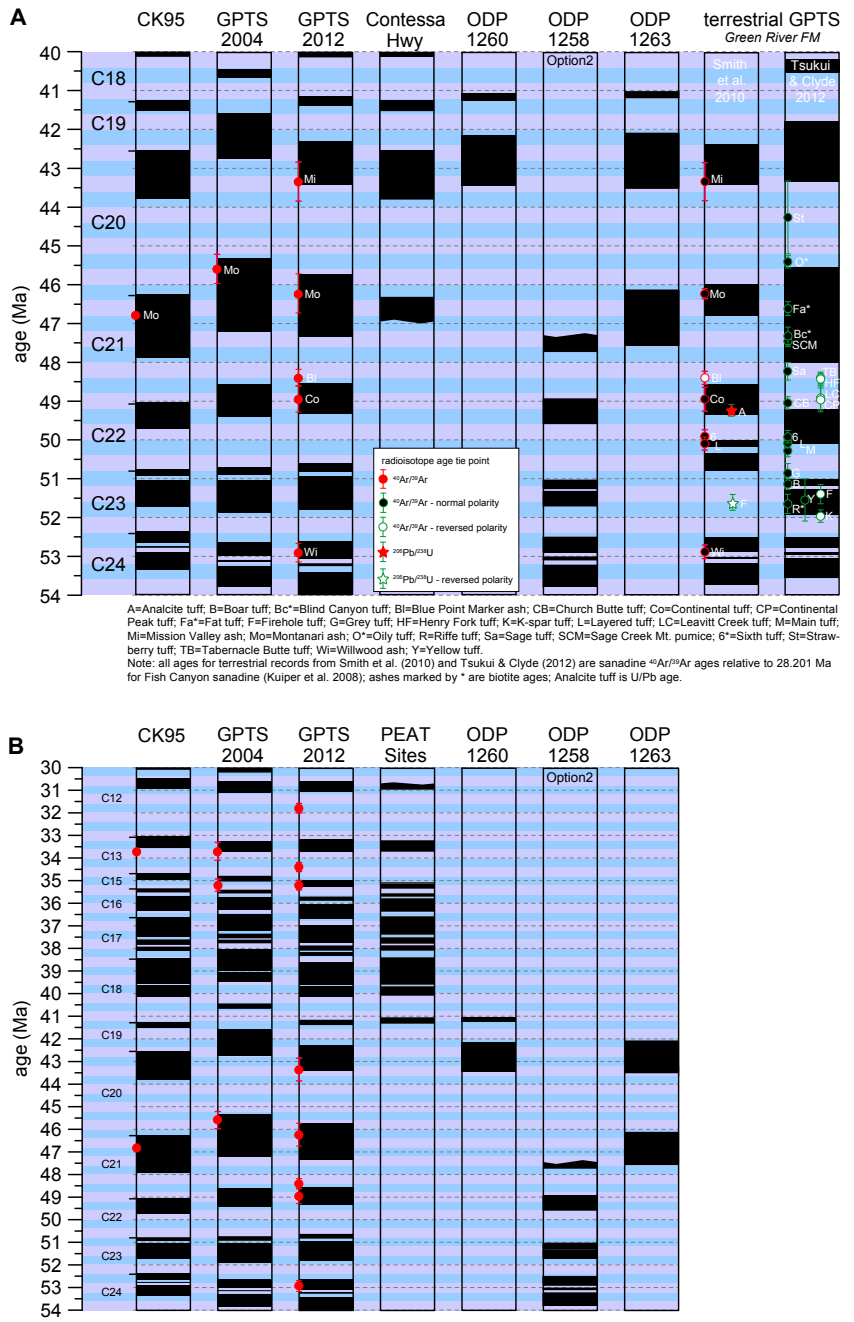

Figure 7. Geomagnetic polarity timescale of CK95 (Cande and Kent, 1995), GPTS2004 (Ogg and Smith, 2004) and GPTS2012 (Ogg, 2012; Vandenberghe et al., 2012) compared to astronomical calibrations of magnetochrons from Contessa Highway (Jovane et al., 2010), PEAT sites (Westerhold et al., 2014), Site 1260 (Westerhold and Röhl, 2013), Site 1258 (Westerhold and Röhl, 2009; Westerhold et al., 2012) and 1263 (this study) from (a) 40-54 Ma and (b) 30-54 Ma. In (a) the terrestrial calibration of the GPTS from the Green River Formation (Smith et al., 2010; Tsukui and Clyde, 2012) is also shown. Small red dots with error bars mark the radioisotopic calibration points used for CK95, GPTS2004, GPTS2012, and Smith et al. (2010); green circles show calibration points for the terrestrial sections used by Tsukui and Clyde (2012). The overview demonstrates the consistent Eocene coverage from 30 to 54 Ma by ODP- and IODP- (PEAT sites) derived stratigraphic data and the discrepancy in the terrestrial GPTS.

results in very uncertain chron durations (see Table S13). From combining both the error in absolute age for the calibration tie points (ash layers, boundaries) and the error in the exact placement of boundaries between marine magnetic anomalies in the CK95 model (Table S13), it is obvious that 
the determination of the exact durations of magnetochrons is much more difficult than assumed in many publications. Once the durations for $\mathrm{C} 21 \mathrm{r}, \mathrm{C} 22 \mathrm{r}$ and $\mathrm{C} 23$ based on the ODP Site 1258 cyclostratigraphy are evaluated by an additional high-resolution bio-, magneto- and cyclostratigraphy at another site, the resulting new precise cycle durations for chrons could help to provide an improved estimate for the deep-sea magnetic anomaly widths as in CK95.

Previous correlation of geological data with the La2011 orbital solution led to a discrepancy between astronomical and radioisotopic ${ }^{40} \mathrm{Ar} /{ }^{39} \mathrm{Ar}$ ages of ash -17 (Storey et al., 2007) derived from Deep Sea Drilling Project (DSDP) Site 550 (Knox, 1984) and the age of the Paleocene-Eocene Thermal Maximum (PETM) (Vandenberghe et al., 2012; Westerhold et al., 2009, 2012). Linking the published cyclostratigraphies for the Paleocene (Westerhold et al., 2008) and early to middle Eocene (Westerhold and Röhl, 2009; Westerhold et al., 2007, 2012) to our ATS across the C21nC21r boundary in $405 \mathrm{kyr}$ cycle 118 at $\sim 47.6 \mathrm{Ma}$ (Fig. $6 \mathrm{~b}$ ) clearly shows that only option 2 (Westerhold et al., 2007, 2012) of the early-to-middle Eocene floating cyclostratigraphies is consistent with our new astronomically tuned age for $\mathrm{C} 21 \mathrm{n}-\mathrm{C} 21 \mathrm{r}$ boundary. Our records spanning the middle Eocene cyclostratigraphic gap provide an absolute age estimate of 55.280 Ma for ash -17 and the onset of the PETM in $405 \mathrm{kyr}$ cycle 139 at $55.930 \mathrm{Ma}$, as in option 2 of the astronomically calibrated Paleocene timescale (Westerhold et al., 2008). This age for the onset of the PETM is consistent with a high-precision radioisotopic $\mathrm{U} / \mathrm{Pb}$ age of 55.72855.964 Ma from bentonite layers within the PETM interval at Spitzbergen (Charles et al., 2011). The absolute age for the onset of the PETM confirmed here at $55.930 \mathrm{Ma}$ is also synchronous with the initiation of North Atlantic flood basalt volcanism (Skaergaard intrusion at $55.960 \pm 0.064 \mathrm{Ma}$; Wotzlaw et al., 2012).

After revision of the Paleocene cyclostratigraphy from deep-sea data (Dinarès-Turell et al., 2014) showing that the Paleocene spans 25 (Hilgen et al., 2010) and not 24 (Westerhold et al., 2008) $405 \mathrm{kyr}$ cycles, and with the complete stratigraphic framework now at hand, we provide absolute astronomical ages for key events in the Eocene and Paleocene for reference (Table 3). Updates for ages of magnetochron boundaries await the uncertainties being solved for the durations of Chrons C22n to C23r. Our complete framework confirms the astronomically calibrated age of the K-Pg boundary of 66.022 $\pm 0.040 \mathrm{Ma}$ (Dinarès-Turell et al., 2014). This is consistent with a recent high-precision radioisotopic $\mathrm{U} / \mathrm{Pb}$ age for the K-Pg boundary of 66.038 Ma (Renne et al., 2013). The major uncertainty in age estimates stems from uncertainties in the exact absolute age assignment of the $405 \mathrm{kyr}$ eccentricity maxima at 56 and $66 \mathrm{Ma}$. According to Laskar et al. $(2011 \mathrm{a}, \mathrm{b})$ the error at $56 \mathrm{Ma}$ is on the order of $50 \mathrm{kyr}$ and at $66 \mathrm{Ma}$ on the order of $60 \mathrm{kyr}$.

The astronomically calibrated age for ash -17 of 55.280 Ma is inconsistent with ${ }^{40} \mathrm{Ar} /{ }^{39} \mathrm{Ar}$ ages using the most recent age calibrations for the FCT dating standard monitor of 28.201 (Kuiper et al., 2008), 28.305 (Renne et al., 2010), 27.93 (Channell et al., 2010), 27.89 (Westerhold et al., 2012), and 28.172 Ma (Rivera et al., 2011) (Fig. S7). Assuming that the $55.280 \mathrm{Ma}$ age for ash -17 is correct, we calculate an absolute age of $\sim 28.10 \mathrm{Ma}$ for the FCT monitor, which is within the error of the $28.172 \mathrm{Ma}$ (Rivera et al., 2011 ) estimate. The age of $28.10 \mathrm{Ma}$ for the FCT leads to an age for the highly reproducible inter-laboratory ${ }^{40} \mathrm{Ar} /{ }^{39} \mathrm{Ar}$ measurements made on the Beloc tektite at the K-Pg boundary that is more than $400 \mathrm{kyr}$ younger than the highly accurate $\mathrm{U} / \mathrm{Pb}$ age (Renne et al., 2013), contradicting the rock clock synchronization (Kuiper et al., 2008). Independent confirmation of the $\sim 28.2 \mathrm{Ma}$ astronomically calibrated age for the FCT (Kuiper et al., 2008; Rivera et al., 2011; Wotzlaw et al., 2014) and the absolute age of the K-Pg boundary of 66.022 Ma (Dinarès-Turell et al., 2014; Kuiper et al., 2008; Renne et al., 2013) place doubt on the astronomically calibrated age for ash -17 . Both the geochemical identification of ash -17 at ODP Site 550 (Knox, 1984) and the relative distance to the onset of the PETM (Westerhold et al., 2009) need revision before any evaluation can be done.

\subsection{Terrestrial vs. deep-sea GPTS}

High-resolution radioisotopic dating of Eocene terrestrial strata, from the Green River Formation in particular, has been utilized during the last 20 years with the aim of improving the Eocene GPTS (Clyde et al., 1997, 2001, 2004; Machlus et al., 2004, 2008, 2015; Shipboard Scientific Party, 1988; Smith et al., 2003, 2004, 2006, 2008a, b, 2010; Tsukui and Clyde, 2012; Westerhold and Röhl, 2009). Although it needs to be stated that the correlation of terrestrial sections and accurate age dating of ash layers is highly complex, we evaluate our new GPTS in comparison with to the terrestrial calibrations (Fig. 7a). Focusing on the latest Green River Formation GPTS calibrations (all adjusted and reported by Smith et al., 2010, and Tsukui and Clyde, 2012, to FCT 28.201 Ma of Kuiper et al., 2008), it becomes very clear that substantial differences in calibration and interpretation exist that are based on very similar data sets.

Because most of the radioisotopic dates for ash layers in the Green River Formation are established on ${ }^{40} \mathrm{Ar} /{ }^{39} \mathrm{Ar}$ ages, they are directly dependent on the absolute age of the FCT standard (see discussion in Westerhold and Röhl, 2009 and Westerhold et al., 2012). High-quality $\mathrm{U} / \mathrm{Pb}$ ages are also available for some ash layers (Smith et al., 2010: Analcite and Firehole tuff; Machlus et al., 2015: Sixth, Layered, Main, Grey, Second, Firehole and 1448 Tuff). The Firehole tuff has a consistent $\mathrm{U} / \mathrm{Pb}$ age of $51.66 \pm 0.19 \mathrm{Ma}$ in Smith et al. (2010) and 51.528 $\pm 0.061 \mathrm{Ma}$ in Machlus et al. (2015). The ${ }^{40} \mathrm{Ar} /{ }^{39} \mathrm{Ar}$ age of the Firehole tuff is $51.40 \pm 0.25 \mathrm{Ma}$ (FCT 28.201 Ma) (Smith et al., 2010). The Firehole tuff, however, was not included by Smith et al. (2010) for recalibrating the GPTS. According to Tsukui and Clyde (2015) 
Table 3. Astronomically calibrated ages of key events in the Eocene and Paleocene.

\begin{tabular}{|c|c|c|c|}
\hline Event & Age (Ma) & Type & Source \\
\hline EOT & 33.89 & $\begin{array}{l}\text { Onset large-scale } \\
\text { glaciation of Antarctica }\end{array}$ & Westerhold et al. (2014) \\
\hline Peak-MECO CIE & 40.05 & Hyperthermal & Westerhold and Röhl 2013 \\
\hline $\mathrm{C} 19 \mathrm{r}$ & 41.51 & Hyperthermal & Westerhold and Röhl 2013 \\
\hline X/K (ETM-3) & 52.83 & Hyperthermal & Westerhold et al. (2012) Opt2 \\
\hline ELMO (ETM-2) & 54.02 & Hyperthermal & Westerhold et al. (2007) Opt2 \\
\hline PETM (ETM-1) & 55.93 & Hyperthermal & Westerhold et al. (2008) Opt2 \\
\hline Peak-PCIM event & 58.10 & $\begin{array}{l}\text { Shift in Pacific and } \\
\text { Atlantic benthic } \\
\text { carbon isotopes }\end{array}$ & Westerhold et al. (2008) Opt2 \\
\hline ELPE (MPBE) & 59.27 & Biotic turnover & Westerhold et al. (2008) Opt2 \\
\hline LDE (Chron 27n) & 62.18 & Hyperthermal & Dinarès-Turell et al. (2014) \\
\hline Dan C2 & $65.82-65.65$ & Hyperthermal & Dinarès-Turell et al. (2014) \\
\hline K-Pg boundary & $66.022 \pm 0.04$ & Impact & Dinarès-Turell et al. (2014) \\
\hline
\end{tabular}

Note: ages for the events from ELPE to $X$ have been adjusted to La2011 (Laskar et al., 2011b).

the Firehole tuff is in a paleomagnetic reversal, likely C23r (see Table DR4 in Tsukui and Clyde, 2012). Unfortunately, the Analcite tuff (U / Pb 49.23 $\pm 0.12 \mathrm{Ma}$; Smith et al., 2010) does not have clear paleomagnetic polarity (Tsukui and Clyde, 2015). Comparison of the radioisotopic ages used by Smith et al. (2010) and their paleomagnetic pattern with the astronomically calibrated GPTS (Fig. 7a) shows consistent results for the Mission Valley ash (in C20n), the Montanari ash (in C21n), the Blue Point Marker ash (in C21r), the Continental tuff (in $\mathrm{C} 22 \mathrm{n}$ ), the Firehole tuff (in $\mathrm{C} 23 \mathrm{r}$ ) and the Willwood ash (in C24n). Inconsistencies are apparent for the Sixth tuff and Layered tuff, which have normal polarity but correlate with C22r in the astronomical GPTS.

Tsukui and Clyde (2012) utilized more ash layers for their calibration of the GPTS, resulting in substantial differences to the GPTS by Smith et al. (2010) from Chron C21n to C24n (Fig. 7b). Some ash layers in the GPTS by Tsukui and Clyde (2012), for example in C21r and C23n, have opposite polarities although they are of similar age. The GPTS of Tsukui and Clyde (2012) is more consistent with the astronomical GPTS for Chron C22 and C23, but the Sixth ash, the Layered tuff and the Main tuff occur in an interval of normal polarity correlated with $\mathrm{C} 22 \mathrm{r}$ in the astronomical GPTS. In contrast, the Firehole tuff, located in an interval of reversed polarity, is positioned in C23n according to the GPTS of Tsukui and Clyde (2012). We would argue that the duration of C23n as estimated by Tsukui and Clyde (2012) is probably too long. A detailed comparison of the GPTS for Chrons C22 and $\mathrm{C} 23$ between terrestrial and deep-sea records is difficult at the moment because the deep-sea and the terrestrial GPTS still need to be examined in detail in the early Eocene, as described above. The error in the mean width of the anomaly profile defined by Cande and Kent (1992, Table 4 therein) for C21r, C22r and C23 is between 12 and $17 \%$ (Table S13), which can also help to explain larger differences in dura- tions between the terrestrial and deep-sea records. A new deep-sea magneto-cyclostratigraphic record is needed to test the ODP Site 1258 results in order to validate the duration of magnetochrons C22 and C23. Nevertheless, it seems that these records align for Chron $\mathrm{C} 24 \mathrm{n}$, suggesting that both astrochronology and radioisotopic dating of terrestrial successions are in agreement for at least this time interval. A more detailed comparison between marine and terrestrial records is well beyond the scope of this paper; a more in-depth synthesis and discussion of terrestrial and deep-sea GPTS for the Eocene needs to be addressed by a future synthesis similar to the Paleogene chapter in the GTS2012 (Vandenberghe et al., 2012).

\subsection{Stability of orbital solutions}

The new $\delta^{13} \mathrm{C}$ records from Sites 702 and 1263 reveal lowamplitude variations in $405 \mathrm{kyr}$ cycles 4, 10 and 16 (Fig. 5), which likely coincide with minima in eccentricity amplitude modulation occurring approximately every 2.4 Myr (Laskar et al., 2004). The $2.4 \mathrm{Myr}$ cycle in the amplitude modulation of geological data and the orbital eccentricity are consistent up to 48-49 Ma (Fig. S6). In older time intervals, the geological data and orbital solution are out of sync suggesting that the short and very long eccentricity component in orbital solutions are correct only back to $48 \mathrm{Ma}$, not to $52-54 \mathrm{Ma}$ as previously thought (Westerhold et al., 2012). This implies that only the stable $405 \mathrm{kyr}$ eccentricity pattern in the La2010 and La2011 solutions can be used for direct astronomical calibration for periods older than 48-50 Ma. Because the orbital solutions La2010d and La2011 (Laskar et al., 2011a, b) show an excellent fit to the internally anchored $\delta^{13} \mathrm{C}$ records the long-term behavior of the INPOP10a (Intégration Numérique Planétaire de l'Observatoire de Paris; Fienga et al., 2011), the ephemeris used for La2010d and La2011 can be considered 
more stable than that of the INPOP08 (Fienga et al., 2009) ephemeris.

The divergence between geological data and astronomical solutions beyond 48-50 Ma has strong implications for the La2010 (Laskar et al., 2011a) and La2011 (Laskar et al., 2011b) orbital models. Both models propose a transition from libration to circulation appearing around $50 \mathrm{Ma}$ in the resonant argument related to $\theta=(s 4-s 3)-2(\mathrm{~g} 4-\mathrm{g} 3)$, the combination of angles in the precession motion of the orbits of Earth and Mars (Laskar et al., 2004; Pälike et al., 2004). Identifying this transition is of high importance because it would provide direct evidence of the chaotic, not quasiperiodic, nature of the solar system (Laskar, 1989) and set the conditions for the gravitational model of the solar system (Laskar et al., 2004). In modern planetary ephemeris the initial conditions are obtained by least-squares fittings to large sets of observational data (Fienga et al., 2008) and thus depend on the accuracy of these data. The point in time when the transition from libration to circulation occurs is sensitive to the initial conditions of the planetary ephemeris solutions. In geological records the chaotic diffusion will be expressed as a prominent change from a $\sim 2.4$ to a very regular $2.0 \mathrm{Myr}$ periodicity in the very long eccentricity cycle (Laskar et al., 2004; Pälike et al., 2004). Due to irregular spacing from four to six long eccentricity cycles between very long eccentricity minima in the geological data from 50 to $60 \mathrm{Ma}$, the chaotic diffusion of the orbital trajectories as proposed in La2010d and La2011 cannot be verified (Fig. S6). This major discrepancy points to inaccuracy in the planetary ephemeris solutions, which are currently limited due to the chaotic behavior of the large asteroids (Laskar et al., 2011b). The transition from libration to circulation needs to be identified in older geological intervals to help to refine orbital models. A precise calculation of Earth's eccentricity beyond $60 \mathrm{Ma}$ is not possible (Laskar et al., 2011b), but geological data, preferably stable carbon isotope data, from 50 to $100 \mathrm{Ma}$ could help to detect this critical transition and provide important information for future orbital models.

\subsection{Comparing the bulk carbon isotope records from 702B and 1263}

One might recognize an interesting aspect of aligning $\delta^{13} \mathrm{C}$ curves at two sites. Given all the factors that influence seawater carbon isotopes and carbonate production and deposition, there is no a priori reason to assume that bulk sediment $\delta^{13} \mathrm{C}$ should covary in records across the ocean basins, and yet they often do, and therefore these patterns are used for chemostratigraphy (Cramer et al., 2003; Zachos et al., 2010; Littler et al., 2014; Saltzman and Thomas 2014). However, the observation that mean $\delta^{13} \mathrm{C}$ values deviate between sites and especially on long timescales should not come as a surprise, especially as ocean circulation is shifting and biota are evolving. The challenge is to extract the orbital patterns for stratigraphic purposes from these records, the relative mod- ulation of which should be similar, even as the means deviate. The Oligocene-Miocene records provide good examples where the $405 \mathrm{kyr}$ cycles can be extracted and correlated even as mean values deviate between records (Zachos et al., 2001; Pälike et al., 2006; Holbourn et al., 2013).

The $\delta^{13} \mathrm{C}$ records in our study do correlate between 41.5 and $44.5 \mathrm{Ma}$ with similar absolute bulk $\delta^{13} \mathrm{C}$ values and similar trends/orbital-scale cyclicity. Between 44.5 and $47 \mathrm{Ma}$, Site 702 is offset relative to Site 1263 by $0.3-0.4 \%$ (Fig. 5a), but trends and overall patterns of orbitally paced events are similar. In the 47 to $49 \mathrm{Ma}$ interval, offset values and trends are different, but the pattern with a double $\delta^{13} \mathrm{C}$ excursion at $\sim 48 \mathrm{Ma}$ is the same. The mismatch around $47.5 \mathrm{Ma}$ could indicate a potential unidentified hiatus between 47 and $48 \mathrm{Ma}$ in one of the sites. Please note that despite the offset from 44.5 to $49 \mathrm{Ma}$ both $\delta^{13} \mathrm{C}$ curves show a very similar trend from 45.5 to $47 \mathrm{Ma}$, including the minimum in amplitude modulation at eccentricity 405 kyr cycle 113. In Fig. S8 both records are plotted on the same as well as on separate $\delta^{13} \mathrm{C}$ axes to demonstrate the coherently corresponding pattern of both records. This clearly exhibits that the chronostratigraphy between sites is consistent and therefore correct. The offset from 44.5 to $48 \mathrm{Ma}$ is only impeding the visual comparison.

In contrast, a somehow problematic interval lies between 47 and $48 \mathrm{Ma}$, where the bulk isotope data exhibit both offset trends and values. The two peaks in Hole 702B bulk $\delta^{13} \mathrm{C}$ data at 47.39 and $47.55 \mathrm{Ma}$ (see Fig. S8) are based on single measurements and therefore should not be overinterpreted, e.g., as $\delta^{13} \mathrm{C}$ excursions or even (mis)used for direct value-to-value correlation to 1263 . The $\delta^{13} \mathrm{C}$ excursion seen at Site 1263 at $47.2 \mathrm{Ma}$ is not well expressed in Hole 702B bulk data. However, the cyclostratigraphy for this Site 1263 interval is straightforward because the $405 \mathrm{kyr}$ cycles can be clearly identified (Fig. 5, cycles $14-16$ ). The $405 \mathrm{kyr}$ cycles 14 and 15 are hard to assign in Hole 702B. Cycle 16 can be identified which correlates to cycle 16 at Site 1263 with the prominent double $\delta^{13} \mathrm{C}$ peaks at 48.0 and $48.1 \mathrm{Ma}$. Cycle 16 is located in $\mathrm{C} 21 \mathrm{r}$ in both records, and thus we can be confident that there is no major gap in the Hole 702B record.

Finally, there might be an interesting divergence in the $\delta^{13} \mathrm{C}$ of surface waters in the South Atlantic during the middle Eocene assuming the bulk $\delta^{13} \mathrm{C}$ signal at Hole 702B and Site 1263 mainly comes from coccolith and planktonic foraminiferal carbonate. The stratigraphic pattern seems consistent between Sites 702 and 1263; therefore we interpret the observed divergence and offset in the $\delta^{13} \mathrm{C}$ signal as a result of changes in the surface water at Site 702. Site 1263 is from the middle of the South Atlantic Gyre and Site 702 is from higher latitude on the edge of the gyre. It might be that differences in surface-water nutrient levels and/or stratification existed. Even though both sites are comprised of slowly accumulated pelagic carbonates, Site 702 would likely have been subject to higher nutrient conditions and/or more variability in nutrient supply, as for example indicated by bio- 
genic silica (radiolarians, silicoflagellates) in the upper middle Eocene section of Site 702. The lower bulk $\delta^{13} \mathrm{C}$ values in the older part of the record at Site 702 could be indicative of higher nutrient levels or a deeper depth of production of calcareous nannoplankton. Given all the variables that control mixed-layer $\delta^{13} \mathrm{C}$-DIC (including also air-sea $\mathrm{CO}_{2}$ exchange), the two sites should not really be expected to have similar bulk $\delta^{13} \mathrm{C}$ values. Low-resolution benthic $\delta^{13} \mathrm{C}$ data from Hole 702B (Katz and Miller, 1991; Fig. S8) show a possible $0.2 \%$ o shift at $\sim 44.5 \mathrm{Ma}$, pointing towards changes in surface and deep-ocean carbon signatures. The similar pattern in bulk $\delta^{13} \mathrm{C}$ data of Sites 702 and 1263 suggests that both sites are recording the primary signal and it is very unlikely that diagenetic alteration affected the signal at both sites in the same way. The shift in bulk $\delta^{13} \mathrm{C}$ data at $44.5 \mathrm{Ma}$ does not influence the stratigraphic interpretation but might be a very interesting feature for further paleoceanographic investigations.

\section{Conclusions}

The closing of the middle Eocene gap and the connection of the $405 \mathrm{kyr}$ cyclostratigraphies of the Eocene and Paleocene completes a fully astronomically calibrated geological timescale for the Cenozoic. Derived absolute ages for the PETM and K-Pg boundary are now consistent with the intercalibration of radioisotopic and astronomical dating methods. Previous discrepancies lie in the uncertainties of orbital solutions beyond $50 \mathrm{Ma}$ and problems in the determination of the absolute age of ash -17 in the early Eocene with respect to cyclostratigraphy (Hilgen et al., 2010; Storey et al., 2007; Westerhold et al., 2009). The new, accurate stratigraphy is a key to exploring, in unprecedented detail, why and how Earth's climate shifted from a greenhouse to icehouse state throughout the Paleogene. Comparison of terrestrial and deep-sea calibrations of the GPTS suggests that ages and durations of Chrons C22 and C23 need to be studied in more detail to solve current discrepancies in the future. The presently observed differences in Chrons C22 and C23 stem from uncertainties in the exact width of the stacked deep-sea anomaly profile of Cande and Kent (1992), the lack of highquality magnetostratigraphy from deep-sea records, and uncertainties in position as well as in age of some ash layers in the terrestrial Green River Formation. Importantly, the comparison between bulk carbonate carbon isotope data and orbital models for Earth's eccentricity reveals inaccuracy in the planetary ephemeris solutions and limits direct astronomical calibration using the short eccentricity cycle to $48 \mathrm{Ma}$.

\section{The Supplement related to this article is available online at doi:10.5194/cp-11-1181-2015-supplement.}

Author contributions. T. Westerhold and U. Röhl designed the study, generated stable bulk isotope data for ODP Site 1263, and applied time series analysis. T. Frederichs conducted the paleomagnetic analysis. S. M. Bohaty generated the bulk isotope data for ODP Site 702, and J. C. Zachos generated bulk isotope data for 1263 . T. Westerhold, U. Röhl, T. Frederichs, S. M. Bohaty and J. C. Zachos interpreted the data and wrote the paper.

Acknowledgements. We thank Monika Segl and her team for stable isotope analyses at MARUM, Alexander Houben and Dyke Andreasen for stable isotope analyses at UCSC, Roy Wilkens (University of Hawaii) for introducing us to the world of core image analysis, Alex Wülbers and Walter Hale at the IODP Bremen Core Repository (BCR) for core handling, and Vera Lukies (MARUM) for assistance with XRF core scanning. This research used samples and data provided by the International Ocean Discovery Program (IODP). IODP is sponsored by the US National Science Foundation (NSF) and participating countries. Financial support for this research was provided by the Deutsche Forschungsgemeinschaft (DFG). The data reported in this paper are tabulated in the Supplement and archived in the Pangaea (www.pangaea.de) database.

The article processing charges for this open-access publication were covered by the University of Bremen.

Edited by: G. Dickens

\section{References}

Aubry, M. P.: From Chronology to Stratigraphy: Interpreting the Lower and Middle Eocene Stratigraphic Record in the Atlantic Ocean, in: Geochronology, Time Scales and Global Stratigraphic Correlation, edited by: Berggren, W. A., Kent, D. V., Aubry, M. P., and Hardenbol, J., SEPM, Spec. Publ., 213-274, 1995.

Cande, S. C. and Kent, D. V.: A New Geomagnetic Polarity Time Scale for the late Cretaceous and Cenozoic, J. Geophys. Res., 97, 13917-913951, 1992.

Cande, S. C. and Kent, D. V.: Revised calibration of the geomagnetic polarity timescale for the Late Cretaceous and Cenozoic, J. Geophys. Res., 100, 6093-6095, 1995.

Channell, J. E. T., Hodell, D. A., Singer, B. S., and Xuan, C.: Reconciling astrochronological and ${ }^{40} \mathrm{Ar} /{ }^{39} \mathrm{Ar}$ ages for the Matuyama-Brunhes boundary and late Matuyama Chron, Geochem. Geophys. Geosys., 11, Q0AA12, doi:10.1029/2010GC003203, 2010.

Charles, A. J., Condon, D. J., Harding, I. C., Pälike, H., Marshall, J. E. A., Cui, Y., Kump, L., and Croudace, I. W.: Constraints on the numerical age of the Paleocene-Eocene boundary, Geochem. Geophys. Geosys., 12, Q0AA17, doi:10.1029/2010gc003426, 2011.

Clement, B. M. and Hailwood, E. A.: Magnetostratigraphy of sediments from Sites 701 and 702, in: Proc. ODP, Sci. Results, 114: College Station, TX (Ocean Drilling Program), edited by: Ciesielski, P. F., Kristoffersen, Y., et al., College Station, TX, Publisher: Ocean Drilling Program, Texas Aand M University 359-366, doi:10.2973/odp.proc.sr.114.156.1991, 1991. 
Clyde, W. C., Zonneveld, J.-P., Stamatakos, J., Gunnell, Y., and Bartels, W. S.: Magnetostratigraphy across the Wasatchian/Bridgerian NALMA Boundary (Early to Middle Eocene) in the Western Green River Basin, Wyoming, J. Geol., 150, 657-669, 1997.

Clyde, W. C., Sheldon, N. D., Koch, P. L., Gunnell, G. F., and Bartels, W. S.: Linking the Wasatchian/Bridgerian boundary to the Cenozoic Global Climate Optimum: new magnetostratigraphic and isotopic results from South Pass, Wyoming, Palaeogeogr. Palaeoclimatol. Palaeoecol., 167, 175-199, 2001.

Clyde, W. C., Bartels, W. S., Gunnell, G. F., and Zonneveld, J.-P.: 40Ar/39Ar geochronology of the Eocene Green River Formation, Wyoming: Discussion, Geol. Soc. Am. Bull., 116, 251-252, 2004.

Cramer, B. S., Wright, J. D., Kent, D. V., and Aubry, M.-P.: Orbital climate forcing of $\delta^{13} \mathrm{C}$ excursions in the late Paleocene - Eocene (chrons C24n-C25n), Paleoceanography, 18, 1097, doi:10.1029/2003PA000909, 2003.

Dinarès-Turell, J., Westerhold, T., Pujalte, V., Röhl, U., and Kroon, D.: Astronomical calibration of the Danian stage (Early Paleocene) revisited: Settling chronologies of sedimentary records across the Atlantic and Pacific Oceans, Earth Planet. Sci. Lett., 405, 119-131, 2014.

Fienga, A., Manche, H., Laskar, J., and Gastineau, M.: INPOP06: a new numerical planetary ephemeris, Astronom. Astrophys., 477, 315-327, 2008.

Fienga, A., Laskar, J., Morley, T., Manche, H., Kuchynka, P., Le Poncin-Lafitte, C., Budnik, F., Gastineau, M., and Somenzi, L.: INPOP08, a 4-D planetary ephemeris: from asteroid and timescale computations to ESA Mars Express and Venus Express contributions, Astronom. Astrophys., 507, 1675-1686, 2009.

Fienga, A., Laskar, J., Kuchynka, P., Manche, H., Desvignes, G., Gastineau, M., Cognard, I., and Theureau, G.: The INPOP10a planetary ephemeris and its applications in fundamental physics Celestial Mechanics and Dynamical Astronomy, Springer, An International Journal of Space Dynamics, 111, 363-385, 2011.

Ghil, M., Allen, M. R., Dettinger, M. D., Ide, K., Kondrashov, D., Mann, M. E., Robertson, A. W., Saunders, A., Tian, Y., Varadi, F., and Yiou, P.: Advanced Spectral Methods for Climatic Time Series, Rev. Geophys., 40, 1003, doi:10.1029/2000RG000092, 2002

Hilgen, F. J.: Astronomical dating in the 19th century, Earth-Sci. Rev., 98, 65-80, 2010.

Hilgen, F. J., Kuiper, K. F., and Lourens, L. J.: Evaluation of the astronomical time scale for the Paleocene and earliest Eocene, Earth Planet. Sci. Lett., 300, 139-151, 2010.

Hilgen, F. J., Abels, H. A., Kuiper, K. F., Lourens, L. J., and Wolthers, M.: Towards a stable astronomical time scale for the Paleocene: Aligning Shatsky Rise with the Zumaia - Walvis Ridge ODP Site 1262 composite, Newsletters on Stratigraphy, 48, 91-110, 2015.

Hinnov, L. A.: Cyclostratigraphy and its revolutionizing applications in the earth and planetary sciences, Geol. Soc. Am. Bull., 125, 1703-1734, 2013.

Hinnov, L. A. and Hilgen, F. J.: Chapter 4 - Cyclostratigraphy and Astrochronology, in: The Geologic Time Scale, edited by: Gradstein, F. M., Ogg, J. G., Schmitz, M. D., and Ogg, G. M., Elsevier, Boston, 63-83, 2012.
Holbourn, A., Kuhnt, W., Clemens, S., Prell, W., and Andersen, N.: Middle to late Miocene stepwise climate cooling: Evidence from a high-resolution deep water isotope curve spanning 8 million years, Paleoceanography, 28, PA002538, 10.1002/2013PA002538, 2013.

Jovane, L., Sprovieri, M., Coccioni, R., Florindo, F., Marsili, A., and Laskar, J.: Astronomical calibration of the middle Eocene Contessa Highway section (Gubbio, Italy), Earth Planet. Sci. Lett., 298, 77-88, 2010.

Katz, M. E. and Miller, K. G.: Early Paleogene benthic foraminiferal assemblage and stable isotopes in the Southern Ocean, in: Proc. ODP, Sci. Results, 114: College Station, TX (Ocean Drilling Program), edited by: Ciesielski, P. F., Kristoffersen, Y., and et al., 49-96, 1991.

Kirschvink, J. L.: The least-squares line and plane and the analysis of paleomagnetic data, Geophys. J. Roy. Astron. Soc., 62, 699718, 1980.

Knox, R. W. O. B.: Nannoplankton zonation and the Palaeocene/Eocene boundary beds of NW Europe: an indirect correlation by means of volcanic ash layers, J. Geol. Soc., 141, 993-999, 1984.

Kuiper, K. F., Deino, A., Hilgen, F. J., Krijgsman, W., Renne, P. R., and Wijbrans, J. R.: Synchronizing Rock Clocks of Earth History, Science, 320, 500-504, 2008.

Laskar, J.: A numerical experiment on the chaotic behaviour of the Solar System, Nature, 338, 237-238, 1989.

Laskar, J., Robutel, P., Joutel, F., Gastineau, M., Correia, A., and Levrard, B.: A long-term numerical solution for the insolation quantities of the Earth, Astronom. Astrophys., 428, 261-285, 2004.

Laskar, J., Fienga, A., Gastineau, M., and Manche, H.: La2010: a new orbital solution for the long-term motion of the Earth, Astronom. Astrophys., 532, 15 pp., doi:10.1051/00046361/201116836, 2011a.

Laskar, J., Gastineau, M., Delisle, J. B., Farrés, A., and Fienga, A.: Strong chaos induced by close encounters with Ceres and Vesta, Astronom. Astrophys., 532, 4 pp., doi:10.1051/00046361/201117504, 2011b.

Littler, K., Röhl, U., Westerhold, T., and Zachos, J. C.: A highresolution benthic stable-isotope record for the South Atlantic: Implications for orbital-scale changes in Late Paleocene-Early Eocene climate and carbon cycling, Earth Planet. Sci. Lett., 401, 18-30, 2014.

Lourens, L. J., Hilgen, F. J., Laskar, J., Shackleton, N. J., and Wilson, D.: The Neogene Period, in: A Geological Timescale 2004, edited by: Gradstein, F., Ogg, J., and Smith, A., Cambridge University Press, UK, 409-440, 2004.

Lurcock, P. C. and Wilson, G. S.: PuffinPlot: A versatile, userfriendly program for paleomagnetic analysis, Geochem. Geophys. Geosys., 13, Q06Z45, doi:10.1029/2012GC004098, 2012.

Ma, W., Tian, J., Li, Q., and Wang, P.: Simulation of long eccentricity $(400 \mathrm{kyr})$ cycle in ocean carbon reservoir during Miocene Climate Optimum: Weathering and nutrient response to orbital change, Geophys. Res. Lett., 38, L10701, doi:10.1029/2011GL047680, 2011.

Machlus, M., Hemming, S. R., Olsen, P. E., and Christie-Blick, N.: Eocene calibration of geomagnetic polarity time scale reevaluated: Evidence from the Green River Formation of Wyoming, Geology, 32, 137-140, 2004. 
Machlus, M. L., Olsen, P. E., Christie-Blick, N., and Hemming, S. R.: Spectral analysis of the lower Eocene Wilkins Peak Member, Green River Formation, Wyoming: Support for Milankovitch cyclicity, Earth Planet. Sci. Lett., 268, 64-75, 2008.

Machlus, M. L., Ramezani, J., Bowring, S. A., Hemming, S. R., Tsukui, K., and Clyde, W. C.: A strategy for cross-calibrating U$\mathrm{Pb}$ chronology and astrochronology of sedimentary sequences: An example from the Green River Formation, Wyoming, USA, Earth Planet. Sci. Lett., 413, 70-78, 2015.

Mann, M. E. and Lees, J. M.: Robust estimation of background noise and signal detection in climatic time series, Climatic Change, 33, 409-445, 1996.

Ogg, J. G.: Chapter 5 - Geomagnetic Polarity Time Scale, in: The Geologic Time Scale, edited by: Gradstein, F. M., Ogg, J. G., Schmitz, M. D., and Ogg, G. M., Elsevier, Boston, 85-113, 2012.

Ogg, J. G. and Bardot, L.: Aptian through Eocene magnetostratigraphic correlation of the Blake Nose Transect (Leg 171B), Florida Continental Margin, in: Proc. ODP, Sci. Results, 171B: College Station, TX (Ocean Drilling Program), edited by: Kroon, D., Norris, R. D., and Klaus, A., College Station, TX, Publisher: Ocean Drilling Program, Texas Aand M University, 1-58, 2001.

Ogg, J. G. and Smith, A. G.: The geomagnetic polarity time scale, in: A Geological Timescale 2004, edited by: Gradstein, F., Ogg, J., and Smith, A., Cambridge University Press, UK, 63-86, 2004

Pälike, H. and Hilgen, F.: Rock clock synchronization, Nature Geosci., 1, 282-282, 2008.

Pälike, H., Laskar, J., and Shackleton, N. J.: Geologic constraints on the chaotic diffusion of the solar system, Geology, 32, 929-932, 2004.

Pälike, H., Norris, R. D., Herrle, J. O., Wilson, P. A., Coxall, H. K., Lear, C. H., Shackleton, N. J., Tripati, A. K., and Wade, B. S.: The Heartbeat of the Oligocene Climate System, Science, 314, 1894-1898, 2006.

Pea, L.: Eocene-Oligocene paleoceanography of the subantarctic South Atlantic: Calcareous Nannofossil reconstructions of temperature, nutrient, and dissolution history, $\mathrm{PhD}$., University of Parma, Parma, Italy, 205 pp., 2011.

Phillips, D. and Matchan, E. L.: Ultra-high precision ${ }^{40} \mathrm{Ar} /{ }^{39} \mathrm{Ar}$ ages for Fish Canyon Tuff and Alder Creek Rhyolite sanidine: New dating standards required?, Geochim. Cosmochim. Acta, 121, 229-239, 2013.

Renne, P. R., Swisher, C. C., Deino, A. L., Karner, D. B., Owens, T. L., and DePaolo, D. J.: Intercalibration of standards, absolute ages and uncertainties in ${ }^{40} \mathrm{Ar} /{ }^{39} \mathrm{Ar}$ dating, Chem. Geol., 145, 117-152, 1998.

Renne, P. R., Mundil, R., Balco, G., Min, K., and Ludwig, K. R.: Joint determination of ${ }^{40} \mathrm{~K}$ decay constants and ${ }^{40} \mathrm{Ar}^{*} /{ }^{40} \mathrm{~K}$ for the Fish Canyon sanidine standard, and improved accuracy for ${ }^{40} \mathrm{Ar} /{ }^{39} \mathrm{Ar}$ geochronology, Geochim. Cosmochim. Acta, 74, 5349-5367, 2010.

Renne, P. R., Deino, A. L., Hilgen, F. J., Kuiper, K. F., Mark, D. F., Mitchell, W. S., Morgan, L. E., Mundil, R., and Smit, J.: Time Scales of Critical Events Around the Cretaceous-Paleogene Boundary, Science, 339, 684-687, 2013.

Rivera, T. A., Storey, M., Zeeden, C., Hilgen, F. J., and Kuiper, K.: A refined astronomically calibrated ${ }^{40} \mathrm{Ar} /{ }^{39} \mathrm{Ar}$ age for Fish Canyon sanidine, Earth Planet. Sci. Lett., 311, 420-426, 2011.

Saltzman, M. R. and Thomas, E.: Chapter 11 - Carbon Isotope Stratigraphy, in: The Geologic Time Scale, edited by: Gradstein,
F. M., Ogg, J. G., Schmitz, M. D., and Ogg, G. M., Elsevier, Boston, 207-232, 2012.

Sexton, P. F., Norris, R. D., Wilson, P. A., Pälike, H., Westerhold, T., Röhl, U., Bolton, C. T., and Gibbs, S.: Eocene global warming events driven by ventilation of oceanic dissolved organic carbon, Nature, 471, 349-352, 2011.

Shipboard Scientific Party: Site 702, in: Proc. ODP, Init. Repts., 114: College Station, TX (Ocean Drilling Program), edited by: Ciesielski, P. F., Kristoffersen, Y., and et al., College Station, TX, Publisher: Ocean Drilling Program, Texas Aand M University, 1988.

Shipboard Scientific Party: Site 1263, in: Proc. ODP, Init. Repts., 208: College Station, TX (Ocean Drilling Program), edited by: Zachos, J. C., Kroon, D., Blum, P., and et al., 1-87, College Station, TX, Publisher: Ocean Drilling Program, Texas Aand M University, 2004.

Smith, M. E., Singer, B., and Carroll, A.: 40Ar / 39Ar geochronology of the Eocene Green River Formation, Wyoming, GSA Bulletin, 115, 549-565, 2003.

Smith, M. E., Singer, B. S., and Carroll, A. R.: Reply, Geol. Soc. Am. Bull., 116, 253-256, 2004.

Smith, M. E., Singer, B., Carroll, A., and Fournelle, J. H.: Highresolution calibration of Eocene strata: 40Ar / 39Ar geochronology of biotite in the Green River Formation, Geology, 32, 393 396, 2006.

Smith, M. E., Carroll, A. R., and Mueller, E. R.: Elevated weathering rates in the Rocky Mountains during the Early Eocene Climatic Optimum, Nature Geosci, 1, 370-374, 2008a.

Smith, M. E., Carroll, A. R., and Singer, B. S.: Synoptic reconstruction of a major ancient lake system: Eocene Green River Formation, western United States, Geol. Soc. Am. Bull., 120, 54-84, $2008 b$.

Smith, M. E., Chamberlain, K. R., Singer, B. S., and Carroll, A. R.: Eocene clocks agree: Coeval 40Ar / 39Ar, U-Pb, and astronomical ages from the Green River Formation, Geology, 38, 527-530, 2010.

Storey, M., Duncan, R. A., and Swisher, C. C., III: PaleoceneEocene Thermal Maximum and the Opening of the Northeast Atlantic, Science, 316, 587-589, 2007.

Suganuma, Y., and Ogg, J. G.: Campanian through Eocene magnetostratigraphy of Sites 1257-1261, ODP Leg 207, Demerara Rise (western equatorial Atlantic), in: Proc. ODP, Sci. Results, 207: College Station, TX (Ocean Drilling Program), edited by: Mosher, D. C., Erbacher, J., and Malone, M. J., College Station, TX, Publisher: Ocean Drilling Program, Texas Aand M University, 1-48, 2006.

Tsukui, K. and Clyde, W. C.: Fine-tuning the calibration of the early to middle Eocene geomagnetic polarity time scale: Paleomagnetism of radioisotopically dated tuffs from Laramide foreland basins, Geol. Soc. Am. Bull., 124, 870-885, 2012.

Vandenberghe, N., Hilgen, F. J., Speijer, R. P., Ogg, J. G., Gradstein, F. M., Hammer, O., Hollis, C. J., and Hooker, J. J.: Chapter $28-$ The Paleogene Period, in: The Geologic Time Scale, edited by: Gradstein, F. M., Ogg, J. G., Schmitz, M. D., and Ogg, G. M., Elsevier, Boston, 855-921, 2012.

Westerhold, T., Röhl, U., Laskar, J., Bowles, J., Raffi, I., Lourens, L. J., and Zachos, J. C.: On the duration of magnetochrons $\mathrm{C} 24 \mathrm{r}$ and $\mathrm{C} 25 \mathrm{n}$ and the timing of early Eocene global warming events: Implications from the Ocean Drilling Program Leg 
208 Walvis Ridge depth transect, Paleoceanography, 22, PA2201, doi:10.1029/2006PA001322, 2007.

Westerhold, T., Röhl, U., Raffi, I., Fornaciari, E., Monechi, S., Reale, V., Bowles, J., and Evans, H. F.: Astronomical calibration of the Paleocene time, Palaeogeogr. Palaeoclimatol. Palaeoecol., 257, 377-403, 2008.

Westerhold, T. and Röhl, U.: High resolution cyclostratigraphy of the early Eocene - new insights into the origin of the Cenozoic cooling trend, Clim. Past, 5, 309-327, doi:10.5194/cp-5309-2009, 2009.

Westerhold, T. and Röhl, U.: Orbital pacing of Eocene climate during the Middle Eocene Climate Optimum and the Chron C19r event: Missing link found in the tropical western Atlantic, Geochem. Geophys. Geosys., 14, 4811-4825, 2013.

Westerhold, T., Röhl, U., McCarren, H. K., and Zachos, J. C.: Latest on the absolute age of the Paleocene-Eocene Thermal Maximum (PETM): New insights from exact stratigraphic position of key ash layers +19 and -17, Earth Planet. Sci. Lett., 287, 412-419, 2009.

Westerhold, T., Röhl, U., and Laskar, J.: Time scale controversy: Accurate orbital calibration of the early Paleogene, Geochem. Geophys. Geosyst., 13, Q06015, doi:10.1029/2012gc004096, 2012.

Westerhold, T., Röhl, U., Pälike, H., Wilkens, R., Wilson, P. A., and Acton, G.: Orbitally tuned timescale and astronomical forcing in the middle Eocene to early Oligocene, Clim. Past, 10, 955-973, doi:10.5194/cp-10-955-2014, 2014.
Wotzlaw, J.-F., Bindeman, I. N., Schaltegger, U., Brooks, C. K., and Naslund, H. R.: High-resolution insights into episodes of crystallization, hydrothermal alteration and remelting in the Skaergaard intrusive complex, Earth Planet. Sci. Lett., 355/356, 199-212, 2012.

Wotzlaw, J.-F., Schaltegger, U., Frick, D. A., Dungan, M. A., Gerdes, A., and Günther, D.: Tracking the evolution of largevolume silicic magma reservoirs from assembly to supereruption, Geology, 41, 867-870, 2013.

Wotzlaw, J.-F., Hüsing, S. K., Hilgen, F. J., and Schaltegger, U.: High-precision zircon $\mathrm{U}-\mathrm{Pb}$ geochronology of astronomically dated volcanic ash beds from the Mediterranean Miocene, Earth Planet. Sci. Lett., 407, 19-34, 2014.

Zachos, J., Pagani, M., Sloan, L., Thomas, E., and Billups, K.: Trends, Rhythms, and Aberrations in Global Climate $65 \mathrm{Ma}$ to Present, Science, 292, 686-693, 2001.

Zachos, J. C., McCarren, H., Murphy, B., Röhl, U., and Westerhold, T.: Tempo and scale of late Paleocene and early Eocene carbon isotope cycles: Implications for the origin of hyperthermals, Earth Planet. Sci. Lett., 299, 242-249, 2010.

Zeeden, C., Rivera, T. A., and Storey, M.: An astronomical age for the Bishop Tuff and concordance with radioisotopic dates, Geophys. Res. Lett., 41, GL059899, doi:10.1002/2014GL059899, 2014. 